\title{
Socrates, Gutenberg, and McLuhan Walk Into a Bar: Internet Reading and the Rise of a New Literacy Paradigm
}

\author{
By Chris Underation*
}

As the Internet rises as a center for reading and writing, many are expressing concerns about the fractured reading habits, shallow knowledge and shorter attention spans encouraged by digital media. Though these concerns are intuitive, they are not quite what they seem. It is not a change in our ability to think and take in information that is the issue. Instead we should understand that a new type of literacy is rising, and this literacy is bringing about a paradigm shift that is every bit as profound as was the change from oral to literate culture. Using Walter Ong's concept of secondary orality within literate culture, this paper explores the likelihood that oral culture and literate culture are being forged into a new type of literacy that restores some of the virtues of oral culture to our society.

Keywords: digital communication, digital literacy, literacy, online reading, secondary orality

\section{Introduction}

It is proverbial to believe we are becoming a people who cannot think clearly (Carr, 2010), write well (Purcell, Buchanan \& Friedrich, 2013; Weatherhead, 2014), or express ourselves acceptably (Bauerlein, 2009). Generally, the reason for these deficiencies is blamed on the rise of technology, the Internet in particular.

These opinions have found a home in the public mind and are now a part of the conventional wisdom regarding the future of literacy and communication.

But it is worth approaching this subject from a different perspective, a more historical perspective. Communication scholar Daniel Czitrom (1982) reminds us that every major advance of communication technology has been met with concerns about its detrimental impact on individuals and on culture. For example, as the telegraph spread breaking news quickly, a writer for The London Spectator opined:

The recording of every event, and especially every crime, everywhere without perceptible interval of time-the world is for purposes of intelligence reduced to a village. All men are compelled to think of all things, at the same time, on imperfect information, and with too little interval for reflection ... the constant diffusion of statements in snippets, the constant excitements of feeling unjustified by fact, the constant formation of hasty or erroneous opinions must, in the end, one would think, deteriorate the intelligence of all to whom the telegraph appeals. (as cited in Czitrom, 1982, p. 19)

\footnotetext{
* Associate Professor, Liberty University, USA.
} 
The rise of motion pictures, radio, and television were also met with worry. Movies spread immorality that would coarsen culture. Radio would turn its listeners into mere marketing channels since advertising could enter the home uninvited, leading to acquisitiveness and poverty (Czitrom, 1982). One of television's drawbacks was that it created a closed culture apart from mass culture, as people remained at home to watch their favorite programs (Hutchinson, 2012).

Looking at these developments as a whole, the history of communication advances is also the history of decreasing attention spans (Borelli, 2015). The 1858 Lincoln-Douglas debates in the United States are considered a bit of a high-water mark for extended North American intellectual engagement, with crowds of more than 10,000 listening for three hours while the speakers sparred over issues (Ong, 2007). As media technologies became rooted in culture, however, our ability to extend this level of attention declined.

Despite this, world history from the 1850 s to the present should be considered as one of great social, humanitarian, and material advance. So how are we to reconcile this advance with the fact that our great media revolutions have typically resulted in more utilitarian communication, shorter writing, facile entertainment, and shorter attention spans (Rekart, 2011)? We will answer this question later in the paper.

Before proceeding, we should define the terms literacy and understanding as the author uses them. "Literacy" is the ability to read and write, and using that ability to collect general knowledge. "Understanding" is the mental processing and synthesizing of information. Understanding is important because it reflects the outcome of literacy (Bortins, 2010). The purpose of literacy is to achieve some outcome; perhaps it is to develop engaged citizens or to obtain some practical knowledge that permits one to achieve a specific task. Literacy and understanding together create socially functional individuals (Bortins, 2010).

\section{Old Worries in a New Context}

We have experienced controversy about literacy and understanding before. For example, the change from oral culture to literate culture was not without its detractors. In the classic Phaedrus, Plato wrote about reservations Socrates had regarding the written word and how it would destroy the search for moral excellence and understanding. These two things-excellence and understandingare what Socrates saw as the main purpose of education and life.

There is a great deal that can be said about Socrates's worries. For our purposes it is enough to say that Socrates felt the written word did not permit meanings to be teased out and developed in the crucible of give-and-take (Plato, 2005). Written words, he said, were fixed things that lacked life or specific meaning, carrying a vague sense of meanings and associations that harmed our ability to fully understand ideas. The end result of literacy, he 
argued, is that humanity will be able to drink in information but have no understanding about how to use and meaningfully apply that information.

Socrates also feared the habit of memorization would be lost if literacy predominated. For him, memory was the way culture was kept alive. Collective memory gives people a sense of interpersonal connectedness and knowledge. It was the habit of memorization, he argued, that gave the virtue handed down from previous generations a beating heart. This made memorization superior to writing, Socrates says, because writing can easily be stillborn. Memory never is.

[Writing is like painting] ... if you ask them something they preserve quite a solemn silence. Similarly with written words: you might think they spoke as if they had some thought in their heads, but if you ever ask them about any of the things they say out of a desire to learn, they point to just one thing, the same each time. And when once it is written, every composition trundles about everywhere in the same way, in the presence both of those who know about the subject and those who have nothing at all to do with it, and it does not know how to address those it should address and not those it should not. When it is ill treated and unjustly abused, it always needs its father to help it; for it is incapable of either defending or helping itself. (Plato, 2005, p. 63)

The lack of life in the written word ultimately ends in a deficit of control over what words and ideas mean, as opposed to oral culture where meanings are shaped via give-and-take. In a literate world, on the other hand, each person is able to access information, place it in a context of their choosing, and then ascribe their own meaning to it. There is ultimately no foundational meaning or negotiated community meaning in knowledge. We can see this truth in areas such as theology and politics. They are divisive because they are important and because our opinion regarding them is not negotiated communally. We develop our understanding, send it into the world, and allow others to interpret (which is to say misinterpret) our meaning apart from our input.

For modern readers, Phaedrus can seem a tedious back and forth of comment, question, explanation, and further question. Ideas never seem to be neatly summed up, and areas of inquiry extend past the point of our interest in them. This is due to a change in our approach to learning and knowledge. It is also due to the loss of something known as mimesis.

Eric McLuhan (2009) describes mimesis as "the process whereby all men (in oral culture) learn" (p. 356). Mimesis is often described as being like a spell where the speaker and the hearer become transformed.

It was a technique cultivated by the oral poets and rhetors and used by everybody for knowing, by merging the knower and the known... under the spell of mimesis, the [hearer of a recitation] loses all relation to merely present personal, person and place, and is transformed into what he perceives. It is not simply a matter of representation but rather one of putting on a completely new mode of being. (p. 359) 
Oral culture is organic. Oral culture and knowledge flow from regular human interaction. Ideas and definitions are tried and strengthened in the backand-forth of question and answer. Learning in this culture, then, is not something imparted by another through interaction with fixed, written ideas. Learning happens when an individual fuses their understanding with that of another, shaping and molding meaning in community.

\section{A New Context Using Old Arguments}

We have been fully immersed in the world of literacy. Unlike Socrates, who saw ideas as living things whose meaning was always being tested by the latest opinion, our present critics of literacy and the online world understand great ideas as fixed things that are to be swallowed whole through slow, deliberate reading.

This is the belief that moved Mark Bauerlein (2009) to write The Dumbest Generation. In this book, he provides a rich statistical case for his view that today's young people are too immersed in online information and are no longer reading important texts or literature. In fact, he argues that reading is happening less and less.

As a member of research and analysis at the National Endowment for the Arts, Bauerlein was responsible for a 2002 report that found a 17-point drop in reading by 18 - to 24 -year-olds and a 15 -point drop in reading among 25 - to 34 year-olds (Bauerlein, 2009). In interpreting this decrease, he draws a connection between increased use of the Internet and the decrease in reading.

To critics, this is evidence that deep reading-and therefore substantive understanding-is not taking place. The implication is clear: we are awash in information but it is shallow and meaningless, and we are becoming dumber as a result.

But that is not the end of the matter. A 2009 NEA study that updated Bauerlein's 2002 study found a 20-point increase in youth and young adult reading (NEA, 2009). Since that time there have been a number conflicting studies that claim reading is down (Rainie and Perrin, 2015; Ludden, 2014) or that the reading public is stronger than ever (Learnalytics, 2015; Zichuhr and Rainie, 2014).

Many of the complaints about online reading echo Socrates's arguments against literacy. Advocates of traditional literacy worry that the lack of slow, in-depth reading of the great books will result in a loss of societal or cultural knowledge. This lack of reading, they claim, means there is no longer a pool of common wisdom upon which citizens may draw. And, without this commonly accepted knowledge, virtue and cultural unity will decrease.

Viewed through the lens of traditional literacy, online literacy appears to portend a fragmented future (Evans, 2014). Eric McLuhan (2009) and Robin Goodfellow (2011) both say the era of literacy is over. The new era is the era of literacies. 
Literacy ... is no longer the keynote of the western culture. That is to say that literacy is obsolete, having been done in when we killed off the reading public, the ground of literacy. As with the Hydra (once her head was lopped off, new heads sprang up in her place), so with literacy: now we see dozens, nay entire litters of...little literacies springing up spontaneously here and there with evident abandon. (McLuhan, 2009, p. 359)

Goodfellow (2011) writes that "a new communications order" is taking shape. This new order is more personal, and as a result "... the contexts of communication practice in the modern world is now so diverse ... that it is not useful to think of literacy education solely in terms of developing generic competences that can be transferred from context to context" (Goodfellow, 2011, p. 132).

In the digital world, it is widely accepted that information has been democratized (Wihbey, 2014). And looking backward to the time when literate culture was rising, we again hear Socrates. He was concerned that literacy meant a loss of control of meaning. Recall that he said literacy "trundled about," removing any sense of local context and direct human interaction in the creation of meaning.

Oral culture saw itself as more communal, and thus more unified (Ong, 2007). Listening to a voice tended to draw people into a common experience. But these instances were smaller and localized. Literate culture, as Socrates pointed out, goes "about everywhere in the same way" (Plato, 2005, p. 63). Though these messages were not localized, they were consistent. This allowed a uniformity of expression and thought (thanks to hermeneutics) to develop across wide geographical areas.

As mentioned earlier, the history of media innovation is the story of shrinking attention spans. A recent study by Gausby (2015) found the average attention span in a 2,000-person study was just eight seconds, down from 12 seconds in 2000. This has resulted in changing habits for information acquisition. We are moving toward less in-depth reading and toward more scanning, keyword spotting and one-time reading of documents (Liu, 2005). Even Nicholas Carr (2010) admits:

Over the last few years I've had an uncomfortable sense that someone, or something, has been tinkering with my brain, remapping the neural circuitry, reprogramming the memory. My mind isn't going ... but it's changing. I feel it most strongly when I'm reading. I used to find it easy to immerse myself in a book or a lengthy article ... that's rarely the case anymore. (p. 5)

It appears that just as the habit of memorization was lost when brains began to orient themselves to reading, they now are starting the process of accommodating to online literacy. According to Maryanne Wolf (2008), humans were never born to read, and "... this invention could come about only because of the brain's extraordinary ability to be shaped by experience. This plasticity at the heart of the brain's design forms the basis for much of who we are, and who we might become" (p. 3). 
So if attention spans have decreased through the development of communication technologies, this is because we have trained our brains to attend less to long-form content than previously (Elias, 2004; Brooks, 2010). It also means that we can reclaim old traits of the brain-or at least a semblance of them-if we alter our habits (Carr, 2010). The online world is not merely an extension of the offline one. It is a new entity that requires the development of different habits of the brain. If we assess these habits in proper context they are not as dire as critics believe.

\section{Literacy's Paradigm Shift}

McLuhan (2009) says, "Each new medium is a new culture that demands a new spin on identity" (p. 258). In the case of literacy, the new spin is one that takes us back into history. And with this, we are ready to address the question asked in the first section of this paper: How do we reconcile the fact that we have had great social, humanitarian, and material advances even as our attention span has been narrowed by our communication technology?

The developed world has seen these advances because our communication breakthroughs have always allowed information to disseminate more quickly and over a wider area. The telegraph promised "a revolution of moral grandeur ... for what is the end to be accomplished but the most spiritual possible? Not the modification or transport of matter, but the transmission of thought" (Czitrom, 1982, p. 10). Moving pictures brought social problems into stark relief, bringing issues of justice close to home. Radio's entertainment created a common national culture and social touchstones. Television knitted together regions by providing standardized network content to cities and towns. The Internet appears to be taking these advances further, allowing ideas and information to spread together and then to be consumed within a specific communal context. The Gausby attention span study (2015) found that we are increasingly capable of switching between levels of awareness as a situation requires, though heavier users of interactive media are better at paying attention in active environments than in more passive ones (such as watching television or listening to speeches).

In order to encourage sustained attention, Gausby says it is important to speak clearly, directly, and personally to an individual. It also fends off distraction if the message defies expectations and is disseminated across media platforms (p. 47). Even with short attention spans, we can take in and encode information into memory, though we have to make a more conscious effort to do so (Wolf, 2008). Gausby's study also hints that we are seeing the return of facets of oral culture.

In his book Orality and Literacy, which examines the differences between oral and literate cultures, Walter Ong (2007) sets forth an idea he calls secondary orality. 
Secondary orality is both remarkably like and remarkably unlike primary orality. Like primary orality, secondary orality has generated a strong group sense, for listening to spoken words forms hearers into a group, a true audience, just as reading written or printed text turns individuals in on themselves. But secondary orality generates a sense for groups immeasurably larger than those of primary oral culture. (Ong, 2007, p. 134)

Socrates worried about literacy killing the negotiated meaning of communally relevant knowledge. The Internet restores this possibility through secondary orality (Cheng, Danescu-Niculescu-Mizil, \& Leskovec, 2014).

Secondary orality is not orality in the traditional sense. In explaining the concept, Ong says broadcast has brought us into the age of secondary orality which is "... essentially a more deliberate and self conscious orality, based permanently on the use of writing and print ..." (Ong, 2007, p. 134). The digital media-blogs, videos, newspapers, social networks-is mostly based on writing and scripted print, and digital communication extends the idea of secondary orality to a point much closer to traditional orality than Ong foresaw.

Traditional orality, as we have already seen, allowed a person to enter into the reality of the speaker via mimesis. It created community and meaning was negotiated through the interplay of ideas; response was immediate. These are also traits of online literacy.

Ong says secondary orality is marked by a sense of connection that results from taking part in a community of ideas, creating a unifying sense among members as they respond to ideas. There is a focus on what is happening in that moment, and there is a sense of ritual that marks one's entry into this orality. All of these are also traits of the online world.

So what we are seeing develop at the intersection of technology and literacy is not a decline of intelligence or a loss of literacy. Instead, a new literacy is rising that strikes a middle ground between traditional oral culture and traditional literate culture. Researchers have found that online readers make mental connections among the information they have stored (Eveland, Seo \& Marton, 2002). This makes thinking less linear (Brockman, 2010; Gausby, 2015). We are not moving from fact to fact in a systematic manner as we did with traditional literacy. We are now moving from concept to concept in a less linear manner, as it was in the era of oral literacy (Conley, 1990; Herrick, 2009).

\section{Secondary Orality and the Online Community}

This lack of systemeticity should not be confused with a lack of depth or meaning. Research is beginning to help us understand how community is created online, and these findings are often counterintuitive. Far from being the wild west of communication, online communities tend to operate rationally.

Tao Zhou (2011), in one of the clearest studies of this type, found there are three traits that stable online communities have. First, the group itself has a clear purpose. Second, group norms are communicated and set forth. These generally mirror the norms within the offline culture. Finally, the individual's 
self perception and intention for joining the group sets the personal boundary for their online behavior with others in the group.

These traits can be readily discerned in online communities, such as those that spring up around news outlets and athletic teams. Overly critical behavior or expressing opinions outside the group's expectations are often censured, and those who do not moderate unacceptable behavior are ostracized (Millington, 2012).

One of the concerns about online literacy is that it creates a series of human islands who do not interact with those in physical proximity. Research, again, paints a slightly different picture for us.

Carlyne Kujath (2011) and Kirsty Young (2011) performed separate studies examining the habits of adults and youth who regularly use social media. Kujath (2011) discovered that, by and large, social networks among the young are an extension of face-to-face relationships. In fact, the research in this area is so clear that the author writes it is "very unusual for a friendship to exist on Facebook or MySpace that has no real-life counterpart" (p. 76). The study notes that $40 \%$ of Kujath's sample had no friends online that they had not already met in person, and $75 \%$ said they use social networks almost exclusively to speak to and share information with people they already know (Kujath, 2011).

Kujath (2011) claims her study demonstrates that the primary attraction of social media use for young people is relationship maintenance. The pattern also appears to hold for adult users.

Young's (2011) work, examining adult social media friending habits, shows that $98 \%$ of social network connections adults make consist of people they know offline. In her findings, Young notes:

The Internet has not replaced traditional forms of communication. Instead, social networking sites amplify offline relationships. Online social networking is just an extension of the types of interactions that people have daily by phone, text message and email, so the line between what is real and what is virtual is beginning to fade. (p. 29)

The use of digital communication spans many areas. For example, social media following a major event contains content followed by strings of comment that challenge, affirm, disagree, or that attempt to place the comment in a different context (Mitchell and Hitlin, 2013). Within professional areas such as journalism, the idea of using online communities to find sources for stories or for crowdsourcing information is changing the field (Knight and Cook, 2013).

Interacting and posting to the network can be quite terrifying as journalists reconcile [themselves to a] loss of control. The network is in control, not you. The amplification that occurs with content in social spaces is not necessarily what journalists want, but what the collective (i.e., community) chooses to spread and bring to the fore ... dealing with constant feedback, comments, suggestions and pressures can leave bloggers and journalists feeling profoundly stressed. (p. 181) 
Each of the behaviors addressed in this section fits an aspect of secondary orality. The digital world has its own wisdom, rules, and beliefs that provide value and meaning for people. It creates community; and it is very much based in the present (Ong, 2007). These actions are based on the written word. And they are a challenge to traditional literacy.

\section{Conclusion}

We are in the midst of a paradigm shift. A change is occurring in literacy. Proponents of traditional literacy often point to our increasingly short attention span as a danger that imperils the development of understanding and human progress. But we should remember that attention spans were increasingly short before the Internet came along, and that all of the media breakthroughs in the last century have tended to result in a narrowing of our ability to focus (Boorstin, 1987).

This should not be our primary concern as we consider the future. Carr (2010) and Wolf (2008) demonstrate that our brains adapt to technology, developing new habits, new categories and classifications, and new approaches to the challenges of the day. This does not mean our present society is in danger. It means we are continuing along a trajectory that began with the development of the first alphabet.

Pre-literate oral culture has provided many durable traditions, such as debate and community making-of-meaning, that continued to enrich the world well after it was supplanted by literate culture (Herrick, 2009). Literate culture has extended the spread of knowledge over vast distances. It has codified important thoughts that have anchored culture for centuries (Bloom, 1994). These traditions will continue to exert a strong influence as we move though an era defined by technology.

Technology is permitting us to strike a better balance between oral and literate culture, and the connection between the two is Ong's secondary orality. An individual can now post an artifact publicly in much the same way that oral culture presented ideas publicly. The nearly instantaneous feedback to the artifact refines or shapes its meaning. The feedback is done in real time. It is done in community. And it is clearly a move away from the traditional literacy paradigm which was not as flexible, interpersonal, or immediate.

The worries that have been expressed by critics are worth considering. But the flaw in their ideas is that they are judging a new, rising literacy-one that is still being formed-by the standards of an old, established literacy. Because of this, the criticisms, though they are well worn, are often inapt.

After centuries of relatively strict separation between literacy and orality, the pendulum is swinging back to a middle ground between the two. This new literacy permits us to combine the best elements of literacy and oralityliteracy's consistent, geographically dispersed ideas and orality's community and dialogue that enhances and molds meaning-into one new, well-rounded paradigm of literacy. 


\section{References}

Bauerlein, M. (2009). The Dumbest Generation: How the Digital Age Stupefies Young Americans and Jeopardizes our Future. New York, NY: Jeremy P. Tarcher/Penguin.

Bloom, H. (1994). The Western Canon. New York, NY: The Berkley Publishing Group.

Boorstin, D. (1987). The Image: A Guide to Pseudo-events in America. New York, NY: Vintage Books/Random House.

Borelli, L. (2015). Human attention spans shortens to 8 seconds due to digital technology: 3 ways to stay focused. Medical Daily. Retrieved from http://bit.ly/1PnqAPE.

Bortins, L. (2010). The Core: Teaching Your Child the Foundations of Classical Education. New York, NY: Palgrave MacMillan.

Brockman, J. (2010). How is the internet changing the way you think? Edge. Retrieved from http://bit.ly/14TEnrm.

Brooks, D. (2010). The medium is the medium. The New York Times. Retrieved from http://nyti.ms/2ar40cb.

Carr, N. (2010). The Shallows: What the Internet is Doing to our Brains. New York, NY: W.W. Norton \& Company.

Cheng, J., Danescu-Niculescu-Mizil, C., Leskovec, J. (2014). How community feedback shapes user behavior. Association for the Advancement of Artificial Intelligence. Retrieved from http://stanford.io/2aMtbWf.

Conley, T. (1990). Rhetoric in the European Tradition. Chicago, IL: University of Chicago Press.

Czitrom, D. (1982). Media and the American Mind: From Morse to McLuhan. Chapel Hill, N.C.: University of North Carolina Press.

Elias, M. (2004). Short attention span linked to TV. USA Today. Retrieved from http://usat.ly/2aeEGoy.

Evans, J. (2014). The great fragmentation: We are all weirdos now. TechCrunch (July 2014). Retrieved from http://tcrn.ch/1weTZN5.

Eveland, W., Seo, M. \& Marton, K. (2002). Learning from the news in campaign 2000: An experimental comparison of TV news, newspapers, and online news. Media Psychology 4, 355-380.

Gausby, A. (2015). Attention Spans: Consumer insights. Microsoft Canada. Retrieved from http://bit.ly/2ar4sqN.

Goodfellow, R. (2011). Literacy, Literacies and the Digital in Higher Education. Teaching in Higher Education, 16(1), 131-144.

Herrick, J. (2009). The History and Theory of Rhetoric: An Introduction, Boston, MA: ( $4^{\text {th }}$ ed.) Pearson.

Hutchinson, P. (2012). Magic windows and the serious life: Rituals and community in early American local television. Journal of Broadcasting \& Electronic Media, 56(1), 21-37.

Knight, M. \& Cook, C. (2013). Social Media for Journalists: Principles \& Practice. Los Angeles, CA: Sage Publishing.

Kujath, C. (2011). Facebook and MySpace: Complement or substitute for face-to-face communication? Cyberpsychology, Behavior, and Social Networking, 14(1-2), 75-78.

Learnalytics (2015). What kids are reading. Learnalytics. Retrieved from http://bit.ly/1qXl8Cj. 
Liu, Z. (2005). Reading behavior in the digital environment: Changes in reading behavior over the past 10 years. Journal of Documentation, 61(6), 700-712.

Ludden, J. (2014). Why aren't teens reading like they used to? NPR: Morning Edition. Retrieved from http://n.pr/1j9Ogqr.

McLuhan, E. (2009). Literacy in a new key: Adjusting to a changing media. Vital Speeches of the Day, (August), 356-361.

Millington, R. (2012). Buzzing Communities: How to Build Bigger, Better, and More Active Online Communities. Machynlleth, Wales UK: FeverBee.

Mitchell, A. \& Hitlin, P. (2013). Twitter reaction to events often at odds with overall public opinion. Pew Research Center. Retrieved from http://pewrsr.ch/1hT9VC3.

NEA (2009). Reading on the rise: A new chapter in American literacy. National Endowment for the Arts. Retrieved from http://bit.ly/2aJIcqv.

Ong, W. (2007). Orality and Literacy. New York, NY: Routledge.

Plato. (2005). Phaedrus. Translated with an Introduction and Notes by Ch. Rowe. New York, NY: Penguin.

Purcell, K., Buchanan, J. \& Friedrich, L. (2013). The impact of digital tools on student writing and how writing is taught in schools. Pew Research Center: Internet, Science \& Tech. Retrieved from http://pewrsr.ch/1nHtSO9.

Rainie, L. \& Perrin, A. (2015). Slightly fewer Americans are reading print books, new survey finds. Pew Research Center Fact Tank. (October 2015). Retrieved from http://pewrsr.ch/1jxgZbf.

Rekart, J. (2011). Taking on multi-tasking. The Phi Delta Kappan (December/January), 6063.

Weatherhead, R. (2014). Say it quick-say it well: the attention span of a modern internet consumer. The Guardian. Retrieved from http://bit.ly/1j15Qph.

Wihbey, J. (2014). The challenges of democratizing news and information: Examining data on social media, viral patters and digital influence. The Shorenstein Center on Media, Politics and Public Policy (June 2014). Retrieved from http://bit.ly/2aLWesV.

Wolf, M. (2008). Proust and the Squid: The Story and Science of the Reading Brain. New York, NY: Harper Perennial.

Young, K. (2011). Social ties, social networks and the Facebook experience. International Journal of Emerging Technologies and Society, 9(1), 20-34.

Zhou, T. (2011). Understanding online community user participation: A social influence perspective. Internet Research, 21(1), 67-81.

Zickuhr, K. \& Painie, L. (2014). A snapshot of reading in America. Pew Research Center: Internet, Science \& Tech. Retrieved from http://pewrsr.ch/2aJJrpk. 
